\title{
Isolasi Lactobacillus sp dari susu segar kemasan dan uji antimikroba terhadap bakteri patogen Salmonella sp dan Streptococcus mutan
}

\author{
Adhayani Lubis*, Oliviti Natali, Ade Arhamni, Masyitah, Ariyanto, Hans Hotma Haposan \\ Marpaung, Linda Panjaitan \\ Fakultas Kedokteran Universitas Prima Indonesia \\ *Korespondensi: adhayaniadhayani@gmail.com \\ DOI: $10.34012 / j p m s . v 3 i 1.1763$ \\ (C) 2021 JPMS. All rights reserved
}

\begin{abstract}
Abstrak
Nilai gizi yang tinggi pada susu merupakan media yang baik untuk pertumbuhan berbagai macam mikroorganisme, baik yang menguntungkan maupun yang dapat membahayakan manusia. Penelitian ini bertujuan menganalisis kemampuan Lactobacillus $s p$ yang diisolasi dari susu segar terhadap bakteri patogen Gram (+) dan Gram (-) yaitu Salmonella sp, Streptococcus mutan secara in vitro. Hasil penelitian menunjukkan total populasi BAL pada susu segar kemasan adalah $200 \times 10^{8} \mathrm{CFU} / \mathrm{g}$. Pada pewarnaan Gram menujukkan hasil pewarnaan Gram yang positif, sedangkan pada uji katalase menjukkan reaksi yang negatif dan uji aktivitas antimikroba yang menggunakan metode difusica kram MRS broth. Susu segar kemasan mampu menghambat Salmonella sp dengan zona hambat tertinggi adalah 11,925 mm sedangkan pada Streptococcus mutans mampu menghambat dengan zona tertinggi yaitu $13,45 \mathrm{~mm}$.
\end{abstract}

Kata kunci: susu, Lactobacillus sp, probiotik, Salmonella sp, Streptococcus mutans

\begin{abstract}
High nutritional value in milk is a good medium for the growth of various kinds of microorganisms, both beneficial and harmful to humans. This study analyzed the ability of Lactobacillus sp isolated from fresh milk against Gram (+) and Gram (-) pathogenic bacteria, namely Salmonella sp., Streptococcus mutans in vitro. The results showed that the total population of LAB in packaged fresh milk was $200 \times 108$ CFU/g. Gram staining showed a positive Gram stain, while the catalase test showed a negative reaction and the antimicrobial activity test used the difusica krama MRS broth method. Packaged fresh milk was able to inhibit Salmonella sp with the highest zone of inhibition was $11.925 \mathrm{~mm}$ while Streptococcus mutans was able to inhibit it with the highest zone of $13.45 \mathrm{~mm}$.
\end{abstract}

Keywords: milk, Lactobacillus sp, probiotics, Salmonella sp, Streptococcus mutans

\section{Pendahuluan}

Susu merupakan bahan makanan yang diyakini mempunyai gizi yang sempurna dan lengkap. Di dalamnya terkandung zat-zat yang diperlukan untuk tubuh dalam perbandingan yang seimbang. Dengan lengkapnya kandungan gizi yang ada, maka susu dapat dipakai sebagai penyempurna makanan yang ada. Tetapi dengan nilai gizi yang tinggi tersebut susu merupakan media yang baik untuk pertumbuhan berbagai macam mikroorganisme, baik mikroorganisme yang menguntungkan maupun mikroorganisme yang dapat membahayakan manusia. ${ }^{1}$ Susu sapi merupakan bahan makanan yang bergizi tinggi karena mengandung zat - zat makanan yang lengkap dan seimbang, seperti protein, karbohidrat, lemak, kalsium, fosfor dan zat besi serta vitamin A, B1 dan C. Susu sapi segar merupakan salah satu bahan pangan fungsional mengandung komponen aktif yang mempunyai fungsi fisiologis dan unutk pencegahan penyakit (osteoporosis, obesitas, hipertensi dan kanker), meningkatkan sistem imun tubuh dan pertumbuhan, serta perkembangan sel otak manusia untuk mencapai kesehatan yang optimal. $^{2}$

Proses pengolahan susu bertujuan untuk memperoleh susu yang beraneka ragam, berkualitas tinggi, berkadar gizi tinggi, tahan simpan, mempermudah pemasaran dan transportasi, sekaligus meningkatkan nilai tukar dan daya guna bahan mentahnya. Proses pengolahan susu selalu berkembang sejalan dengan berkembangnya ilmu di bidang tekologi pangan. 
Dengan demikian semakin lama akan semakin banyak jenis produk susu yang dikenal. Hal ini sangat menggembirakan dan merupakan langkah yang sangat tepat untuk mengimbangi laju permintaan pasar.

Secara alami, susu mengandung mikroorganisme kurang dari $5 \times 10^{3}$ per $\mathrm{ml} \mathrm{jika} \mathrm{diperah}$ dengan cara yang benar dan berasal dari sapi yang sehat. Berdasarkan SNI 01-6366-2000, batas cemaran mikroba dalam susu segar adalah Total Plate Count (TPC) $<3 \times 10^{4} \mathrm{cfu} / \mathrm{ml}$, koliform $<1 \times 10^{1} \mathrm{cfu} / \mathrm{ml}$, Staphylococcus aureus $1 \times 10^{1} \mathrm{cfu} / \mathrm{ml}$, Escherichia coli negatif, Salmonella negatif, dan Streptococcus group B negatif. Beberapa bakteri seperti Camphylobacter jejuni, E.coli, dan Salmonella sp. Dilaporkan mengontaminasi susu dengan prevalensi kecil. Bakteri Salmonella sp merupakan bakteri berbahaya yang dikeluarkan dari saluran pencernaan hewan dan manusia bersama dengan feses. Salmonella $s p$ merupakan salah satu yang sering mengontaminasi susu di samping Salmonella sp. Berdasarkan SNI 016366-2000, pemeriksaan Salmonella $s p$. dilakukan secara kualitatif dan harus negatif. ${ }^{3}$

Lactobacillus $s p$ banyak ditemukan di alam dan spesiesnya banyak digunakan dalam industri makanan. Lactobacillus sp ditemukan disubtrat yang mengandung karbohidrat dan bahkan di membran mukosa pada manusia dan hewan. Terutama pada bagian oral kapital, pencernaan dan vagina, juga ditemukan di makanan permentasi atau keju. Lactobacillus $s p$ bersifat permentatif dan juga aerotoleran (bisa tumbuh di aerob dan anaerob), dan juga suka didaerah asam atau di $\mathrm{pH}$ yang rendah dan kebanyakan Lactobacillus sp diklasifikasi probiotik.

Probiotik diterjemahkan sebagai mikroorganisme, bila dikonsumsi dalam jumlah yang banyak dapat memberikan dampak bagi yang konsumsi. Berdasarkan WHO ada 2 kriteria suatu bakteri yang digolongkan oleh probiotik, yaitu tahan terhadap asam (keasaman lambung dan garam empedu) dan memiliki efek antagonistik terhadap berbagai macam patogen. ${ }^{4}$

Penelitian ini bertujuan Penelitian ini bertujuan menganalisis kemampuan Lactobacillus $s p$ yang diisolasi dari susu segar terhadap bakteri patogen Gram (+) dan Gram (-) yaitu Salmonella sp, Streptococcus mutan secara in vitro.

\section{Metode}

Penelitian ini merupakan penelitian eksperimen laboratorik dengan menggunakan difusi cakram. Sampel yang digunakan pada penelitian ini adalah produk susu segar kemasan yang dijual di supermarket di Kota Medan. Peralatan yang digunakan untuk penelitian ini yaitu autoklaf, laminar air flow, petri, takar, tabung reaksi, tabung eppendorf 0.51 .5 dan $2 \mathrm{ml}$, erlenmeyer, pipet mikro, jarum ose, inkubator, hot plate stirrer, sentrifus, kaca benda, mikroskop, lampu spiritus, aluminium foil, kertas saring, kertas wrap. Bahan-bahan yang digunakan dalam penelitian ini yaitu susu segar, aquades, Safranin, MRS Broth, kristal violet, alkohol 70\%, nutrien agar, nutrien Broth, Salmonella sp, Streptococcus mutan. Data yang dikumpulkan ditabulasi dengan menggunakan perangkat lunak Microsoft Office Exel 2010 yang selanjutnya akan ditampilkan dalam bentuk tabel, dan grafik.

\section{Hasil}

Berdasarkan data yang diperoleh dari hasil penelitian didapat hasil pengukuran zona hambat uji antimikroba pada susu segar terhadap bakteri Streptococcus mutan.

Tabel 1. Hasil pengukuran zona hambat uji antimikroba terhadap bakteri Salmonella sp

\begin{tabular}{ccccccc}
\hline \multirow{2}{*}{ Bakteri } & \multicolumn{5}{c}{ Zona Hambat (mm) } \\
\cline { 2 - 7 } & Isolasi W1 & Isolasi W2 & Isolasi W3 & Isolasi W4 & Isolasi W5 & Kontrol (-) \\
\hline Salmonella sp & & & & & \\
Uji 1 & $8,8 \mathrm{~mm}$ & $8,1 \mathrm{~mm}$ & $6,6 \mathrm{~mm}$ & $7,15 \mathrm{~mm}$ & $7,35 \mathrm{~mm}$ & $6 \mathrm{~mm}$ \\
Uji 2 & $10,725 \mathrm{~mm}$ & $12,15 \mathrm{~mm}$ & $11,4 \mathrm{~mm}$ & $15,65 \mathrm{~mm}$ & $16,5 \mathrm{~mm}$ & $6 \mathrm{~mm}$ \\
Rata - Rata & $9,7625 \mathrm{~mm}$ & $10,125 \mathrm{~mm}$ & $9 \mathrm{~mm}$ & $11,4 \mathrm{~mm}$ & $11,925 \mathrm{~mm}$ & $6 \mathrm{~mm}$ \\
\hline
\end{tabular}


segar sebagai uji antimikroba terhadap bakteri Salmonella sp pada isolasi W1, W2, W3, W4, W5 dan kontrol (-) memiliki efektivitas sebagai antimikroba yang menghambat pertumbuhan bakteri Salmonella sp. Pada isolasi W1 di dapatkan zona hambat sebesar 9,7625 mm, $10,125 \mathrm{~mm}$ pada isolasi $\mathrm{W} 2,9 \mathrm{~mm}$ pada isolasi W3, pada isolasi W4 11,4 mm dan $11,925 \mathrm{~mm}$ pada isolasi W5, pada kontrol (-) $6 \mathrm{~mm}$. Ini menunjukkan bahwa semakin tinggi aktivitas antimikroba BAL semakin besar zona hambatnya, kontrol (-) yang digunakan adalah akuades sebesar $6 \mathrm{~mm}$.

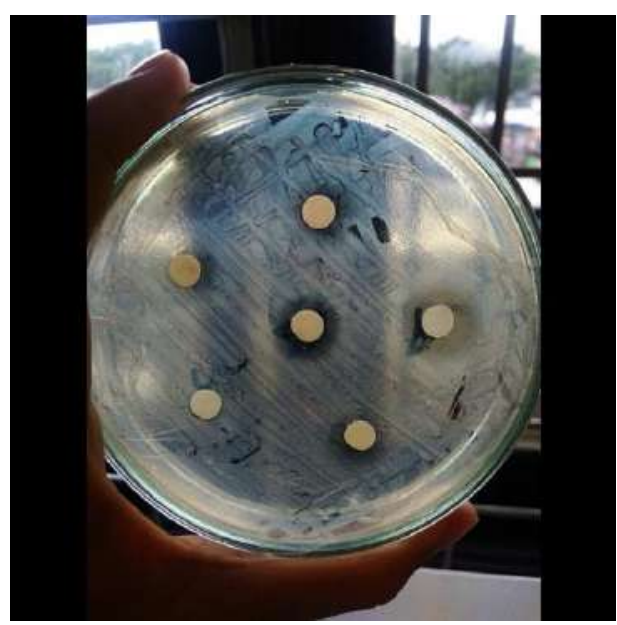

Gambar 1. Zona hambat pada bakteri Steptococcus mutan

Tabel 2. Hasil Pewarnaan Gram, Uji Katalase dan Tipe Fermentasi Isolat BAL

\begin{tabular}{ccc}
\hline \multirow{2}{*}{ Isolat BAL } & \multicolumn{2}{c}{ Karakteristik Biokimia } \\
\cline { 2 - 3 } & Pewarnaan Gram & Uji Katalase \\
\hline W1 & Positif & Negatif \\
W2 & Positif & Negatif \\
W3 & Positif & Negatif \\
W4 & Positif & Negatif \\
W5 & Positif & Negatif \\
\hline
\end{tabular}

Pada tabel 2 hasil isolat BAL W1, W2, W3, W4 dan W5 pada pewarnaan memiliki hasil pewarnaan Gram positif, dan pada uji katalase isolat BAL W1, W2, W3, W4 dan W5 memiliki hasil uji katalase negatif.

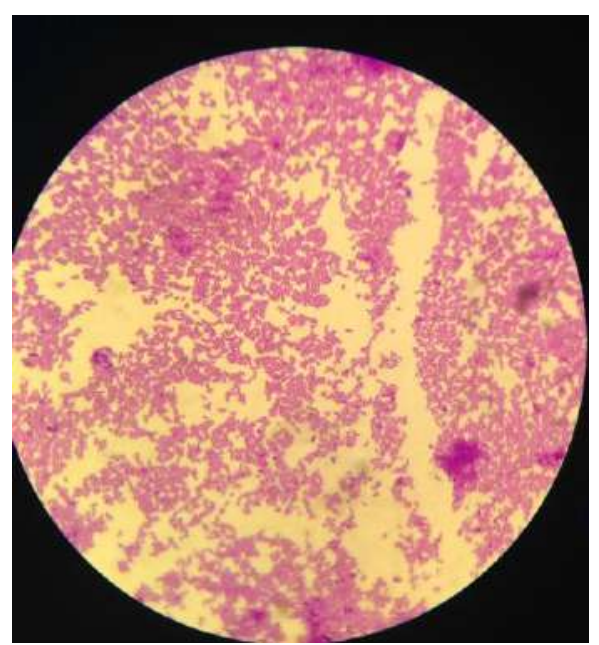

Gambar 2. Pewarnaan Gram pada Lactobaccilus dengan pembesaran $100 x$

\section{Pembahasan}

Hasil uji yang dilakukan dengan menggunakan susu segar sebagai uji antimikroba terhadap bakteri Salmonella sp pada isolasi W1, W2, W3, W4, W5 dan kontrol (-) menunjukkan efektivitas sebagai antimikroba yang menghambat pertumbuhan bakteri Salmonella sp. Jumlah total koloni pada penelitian yang dilakukan ini memenuhi persyaratan sediaan dengan target kerja. Menurut SNI ambang batas total bakteri pada susu sapi murni maksimal sebesar $3000.000\left(3 \times 10^{6}\right) \mathrm{CFU} / \mathrm{ml}$ sehingga susu sapi murni pada penelitian ini masih memenuhi ambang batas yang ditetapkan oleh SNI. ${ }^{5}$

Pada penelitian uji katalase yang dilakukan sejalan dengan yang dilakukan oleh Sari dkk (2012) di mana hasil uji negatif karena tidak menunjukkan adanya busa atau buih. Jika adanya gelembung udara menandakan hasil uji positif, jika tidak berarti hasil uji negatif. ${ }^{6} \mathrm{Uji}$ katalase digunakan untuk mengetahui aktivitas katalase pada sampel bakteri. Enzim katalase berperan dalam memecah $\mathrm{H}_{2} \mathrm{O}_{2}$ (Hidrogen Peroksida) menjadi $\mathrm{H}_{2} \mathrm{O}$ dan $\mathrm{O}_{2}$. Hasil uji katalase positif ditandai dengan adanya gelembung-gelembung oksigen. ${ }^{7}$

Uji pewarnaan Gram dilakukan dengan cara metode pengecatan Gram.menunjukkan sel Gram positif akan berwarna biru atau ungu dan sel Gram negatif akan berwarna kemerahan. ${ }^{6}$ Menurut Leboffe \& Pierce (2011) kemampuan untuk tahan terhadap proses 
decolorization tidak didasarkan pada perbedaan konstruksi dinding antara sel Gram positif dan Gram negatif. Dinding sel Gram negatif mempunyai kandungan lipid yang lebih tinggi dikarenakan adanya membran luar dan lapisan peptidoglikan yang lebih tipis dibandingkan dengan bakteri Gram positif. Alkohol atau aseton yang digunakan sebagai decolorizer mampu mengekstrak lipid menyebabkan dinding sel Gram negatif menjadi berpori dan tidak mampu untuk menyisakan kompleks kristal violet-iodin sehingga menyebabkan kehilangan warna. Lapisan peptidoglikan yang tebal dapat menjebak kompleks Kristal violet-iodin secara lebih efektif sehingga sel Gram positif lebih tahan terhadap proses decolorization. ${ }^{8}$

Proses decolorozation adalah proses yang sangat penting dalam pewarnaan Gram. Sangat mungkin terjadi over decolorize jika telalu lama meninggalkan alkohol terlalu lama menyebabkan warna sel menjadi kemerahan pada sel Gram positif. Dan juga ada kemungkinan under decolorize dan menghasilkan sel Gram positif menjadi berwarna ungu. Usia dari kultur juga menentukan keberhasilan dari hasil pewarnaan Gram. Kultur Gram positif yang lebih tua bisa kehilangan kemampuan untuk menahan decolorization dan memberikan hasil seperti Gram negatif. ${ }^{9}$

Selain untuk nutrisi, Lactobacillus dikenal untuk menghasilkan berbagai senyawa yang mengerahkan aksi antimikroba langsung menuju melawan bakteri dan virus, meskipun efek pada virus belum terdokumentasi dengan baik pada tingkat molekuler. Asam laktat dapat dianggap sebagai kunci senyawa antimikroba yang dihasilkan oleh Lactobacilli. Misalnya, aktivitas antimikroba yang kuat dari $L$. rhamnosus GG terhadap S. enterica serovar Typhimurium itu terbukti karena akumulasi asam laktat. Selain mengeluarkan kegiatan melalui menurunkan $\mathrm{pH}$ dan melalui bentuk terdisosiasi, asam laktat juga dikenal dengan fungsinya sebagai permeabilizer dari membran gram negatif bakteri luar, yang memungkinkan senyawa lain untuk bertindak sinergis dengan asam laktat. Sebagai tambahan, asam organik seperti asam laktat dapat menangkap elemen penting bagi pertumbuhan, seperti besi. ${ }^{10}$

Bakteriosin mempunyai efek bakterisida atau bakteriostatik terhadap bakteri yang sensitif baik yang patogen maupun bakteri perusak atau pembusuk. ${ }^{11}$ Bakteriosin sebagai agen biopreservatif sangat potensial digunakan untuk mengendalikan beberapa bakteri kontaminan. Secara umum kondisi optimum produksi bakteriosin dipengaruhi oleh fase pertumbuhan, $\mathrm{pH}$ media, suhu inkubasi, jenis sumber karbon, jenis sumber nitrogen, dan konsentrasi $\mathrm{NaCl}$. Faktor $\mathrm{pH}$ media berpengaruh terhadap pertumbuhan sel bakteri sehingga mempengaruhi produksi bakteriosin. Produksi bakteriosin meningkat dengan meningkatnya $\mathrm{pH}$ hingga $\mathrm{pH}$ optimum, selanjutnya mengalami penurunan. Sementara itu faktor suhu berpengaruh terhadap meningkatnya produksi bakteriosin sekaligus dapat membunuh BAL yang bersangkutan. ${ }^{12}$

\section{Kesimpulan}

Dari hasil penelitian yang dilakukan didapatkan jumlah total koloni bakteri asam laktat dari susu segar kemasan yang dilihat secara makroskopik yaitu $200 \times 10^{8}$ CFU/g.BAL yang diisolasi dari susu segar menghasilkan senyawa antimikroba yang efektif melawan bakteri Gram positif dan Gram negatif yang digunakan dalam penelitian ini, yaitu Streptococcus mutans, dan Samonella sp.

\section{Referensi}

1. Grahatika R. Identifikasi Dan Pemeriksaan Jumlah Total Bakteri Pada Susu Sapi di Kabupaten Karanganyar. Fakultas Farmasi Universitas Muhammadiyah Surakarta. 2009

2. Nurhidayah $M$, Ginting $S$, Lubis Z. Pengaruh Konsentrasi Susu Sapi Segar Dan Konsentrasi Dekstrin Terhadap Mutu Minuman Cokelat Instan. J.Rekayasa Pangan dan Pert. Vol. 2 No. 3: 2014

3. Suwito W. Bakteri Yang Sering Mencemari Susu: Deteksi, Patogenesis, Epidemiologi, dan Cara Pengendaliannya. Jurnal Penelitian dan Pengembangan Pertanian Vol. 29 No. 3: 2010

4. Widiyaningsih EN. Peran Probiotik Untuk Kesehatan. Jurnal Kesehatan Vol. 4 No. 1: 14-20. 2011.

5. Nahak RJ, Khotimah S, Turnip M. Aspek mikrobiologis susu sapi murni dengan penambahan sari rimpang Bangle (Zingiber cassumunar Roxb). Jurnal Protobiont Vol.3 No.3: 2014. 
6. Sari AR, Nofiani R, Puji A. Karakterisasi Bakteri Asam Laktat Genus Leuconostoc Dari Pekasam Ale-Ale Hasil Formulasi Skala Laboratorium. Jurnal Kimia Khatulistiwa Vol.1 No.1: 2012.

7. Wennanda NG, Kasim AN. Pembuatan Minuman Fermentasi Ubi Jalar Merah (Ipomea batatas) dengan Menggunakan Starter Dadih dari Berbagai Daerah di Sumatra Barat. Fakultas Teknologi Pertanian Universitas Andalas. 2012.

8. Leboffe M, Pierce B. A Photographic Atlas for the Microbiology Laboratory. 4th Edition, Morton, Englewood. 2011.

9. Fachrial E. Isolasi, Aktivitas Antimikroba, Karakterisasi Bakterosin Dan Identifikasi Molekular 16sRrna Bakteri Asam Laktat Dari Dadih Asal Kabupaten Solok Sumatera Barat. Universitas Andalas. 2015.

10. Lebeer S, Vanderleyden J, De Keersmaecker SC. Genes and molecules of lactobacilli supporting probiotic action. Microbiol Mol Biol Rev.72(4):728-64. doi: 10.1128/MMBR.00017-08. 2008.

11. Nurliana, Sudirman I, Sudarwanto $M$, Soejoedono RR. Pengaruh Bakteriosin Produksi Bakteri Asam Laktat Isolat Indonesia terhadap Jumlah Bakteri dalam Susu Pasteurisasi. Agripet. 9(1): 50-56. 2009.

12. Usmiati S, Marwati T. Seleksi Dan Optimasi Proses Produksi Bakteriosin Dari Lactobacillus Sp. J.Pascapanen 4(1) : 27-37. 2007. 